\title{
Effects of Aqueous Leaf Extract of Mucuna Pruriens (Linn.) on the Weight and Histology of the Testis and Epididymis in Adult Male Wistar Rats
}

\author{
${ }^{* 1}$ ORHERUATA, RA; ${ }^{2}$ EJEGUO, A; ${ }^{3}$ SAKPA, CL
}

Department of Anatomy, School of Basic Medical Sciences, College of Medicine, University of Benin, Benin City, Edo State, Nigeria

*Corresponding Author Email: ufuoma6466@gmail.com

\begin{abstract}
Mucuna pruriens, a leguminous plant common to Africa and Asia has been used for managing infertility in males, disorder of the nervous system, and also as an aphrodisiac. This study was aimed at investigating the effect of aqueous leaf extract of Mucuna pruriens on the weight of the animals, reproductive organs (testis and epididymis) and histology of the testis and epididymis. Twenty- five adult male Wistar rats weighing above $200 \mathrm{~g}$ were randomized into five (5) groups consisting five (5) rats each. Group A received $1 \mathrm{ml}$ sterile water via oral route to compensate for stress of administration incurred in the treated groups. Group B1 and B2 received $500 \mathrm{mg} / \mathrm{kg}$ body weight via oral route for 4 and 8 weeks respectively and group $\mathrm{C} 1$ and $\mathrm{C} 2$ received $1500 \mathrm{mg} / \mathrm{kg}$ body weight of extract via oral route daily for 4 and 8 respectively. The extract did not cause any significant change in the body weight of the animals. A significant decrease $(\mathrm{P}<0.05)$ was also observed in the testis of rats in groups $\mathrm{C} 2$ while a significant increase $(\mathrm{P}<0.05)$ was observed in the right epididymis of rats in group B2 and $\mathrm{C} 1$ and left epididymis of rats in group B2. Histological findings revealed distortion of the sequential arrangement of spermatogenic cells in the seminiferous tubule epithelium, absence of spermatozoa and immature sperm cells in the lumen of the seminiferous tubule lumen. Scanty spermatozoa were observed in the epididymal lumen of rats in groups B1 and C2. Findings from this study indicated that Mucuna pruriens had an anti-fertility effect on adult male Wistar rat. Data was analyzed using SPSS/IBM statistical package version 20 and the statistical method employed was ANOVA.
\end{abstract}

DOI: https://dx.doi.org/10.4314/jasem.v23i5.8

Copyright: Copyright $\odot 2019$ Orheruata et al. This is an open access article distributed under the Creative Commons Attribution License (CCL), which permits unrestricted use, distribution, and reproduction in any medium, provided the original work is properly cited.

Dates: Received: 19 March 2019; Revised: 22 May 2019; Accepted 23 May 2019

Key word: Mucuna pruriens, weight, testis and epididymis

The testes (Singular testis) are from the Greek word orchis, commonly known as testicles are the male gonads in animals. The testicles are components of both the reproductive and endocrine system. Their major functions are to produce sperm and androgens, primarily testosterone (Sierens et al., 2005) and three layers of tunics invest each testis i.e. tunica vaginalis, tunica albuginea and tunica vasculosa (Tintinalli, 2004). Spermatogenesis, which begins at puberty, is a sequence of events involving the biological transformation of spermatogonia into mature sperms within the seminiferous tubules of the testis over an extended period of time while spermiogenesis involves the gradual transformation of spermatids into four mature sperm (spermatozoa), the entire process takes approximately 74 days and approximately 360 million sperm cells are produced daily. (Moore and Persaud, 2008). The epididymis is a comma-shaped elongated structure seen on the surface of the testis posteriorly (Moore et al., 2010). It is an accessory organ in male located between the efferent ducts and the vas deferens (Sullivan 2004 and O'Hara et al., 2011). Newly formed sperms are transported to the epididymis by the efferent ductus of the testis and is made up of three parts mainly, with each part made up of a lumen and an epithelium that is polarized and contains mainly principal and basal cells (Lasserre et al., 2001; Dacheux et al., 2005. The use of plant as food and treatment of diseases is as old as mankind itself. Due to donkey years of struggle to protect oneself from disease, humans were led to seek for cure from different parts of plants, this brought about the knowledge of the use of herbs. (Stojanoski, 1999). Mucuna as a genu is part of the Fabaceae family and belong to the subfamily papilionaceae (Evans, 2002). Mucuna pruriens is commonly found in the tropics and subtropical parts of the world and is a reliable dietary source of proteins (Janardhanan et al., 2003; Pugalenthi et al., 2005) since it contains high concentration of protein (23-35\%). Its common English names include Velvet Bean, Florida Velvet Bean, Yokohama Velvet Bean, Cowage, Cowitch. It is commonly known in Nigeria as Devil's Bean (USDA GRIN Taxonomy, 2015). It is renowned for the extreme itching produced when it comes in contact with the skin, especially the tender leaves of the plant 
and the pods of the seeds (Andersen et al., 2015). The itching property is caused by a protein called mucunain (Reddy et al, 2008). Matured seed of Mucuna pruriens contains 3.1-6.1\% L-Dopa while about $0.5 \%$ of L-Dopa is present in the leaves. Its leaves contain flavonoid, saponins, tannins, cardiac glycoside, alkaloids, carbohydrate and anthroquinones (Vadivel et al., 2010). Various parts of Mucuna pruriens plays different role in treating disease conditions such as infertility, diabetes, snake bite and parkinsonism (Alo et al., 2012). Due to the fact that various parts of the plants have been used to treat infertility, this study was aimed at investigating the effect of aqueous leaf extract of Mucuna pruriens on the body weight, epididymal and testicular weights and histology of the testis and epididymis of adult male Wistar rats.

\section{MATERIALS AND METHODS}

The leaves of Mucuna pruriens were collected from a farm at Orogun in Ughelli North Local Government Area, Delta State. The plant identity was confirmed at the department of Plant Biology and Biotechnology, University of Benin, Benin City, with a herbarium specimen (voucher number UBHm358) deposited.

Extraction of plant: Fresh leaves of Mucuna pruriens were air dried at room temperature, milled into fine powder, soaked in distilled water for 24 hours and filtered. The filtrate was evaporated at $40^{\circ} \mathrm{C}$ using a water bath. The residue was stored in a refrigerator at the Department of Anatomy, University of Benin, Benin City. An aliquot portion of the residue was dissolved in appropriate quantity of distilled water for use during the experiment.

Table 1. Experimental Design

\begin{tabular}{lll}
\hline Groups & $\begin{array}{l}\text { Duration Of } \\
\text { Experiment }\end{array}$ & Doses \\
\hline A & 4 and 8 & $1 \mathrm{ml} \mathrm{sterile} \mathrm{water}$ \\
(CONTROL) & weeks & \\
B1 & 4 weeks & $500 \mathrm{mg} / \mathrm{kg}$ bw M.pruriens \\
B2 & 8 weeks & $1500 \mathrm{mg} / \mathrm{kg} \mathrm{bw}$ M.pruriens \\
C1 & 4 weeks & $500 \mathrm{mg} / \mathrm{kg} \mathrm{bw}$ M.pruriens \\
C2 & 8 weeks & $1500 \mathrm{mg} / \mathrm{kg}$ bw M.pruriens \\
\hline
\end{tabular}

At the end of each experimental period, the animals were weighed and under chloroform anesthesia, a midline incision was done in the ventral abdominal walls of the animals. The testes and epididymis were excised, weighed and fixation was carried out using Bouin's fluid for 16 - 18 hours and processed histologically using $\mathrm{H} \& \mathrm{E}$ staining technique. Photomicrograph of the tissue sections were taken at different magnification using a Leica DM750 research microscope.

\section{RESULTS AND DISCUSSION}

In this study, the extract did not cause any significant change in the body weight of rats in all treated groups, which was at variance with the research conducted by Odebiyi et al., (1991), where an increase was observed following administration of ethanolic extract of $M$. pruriens leaf. This could be as a result of method of extraction.

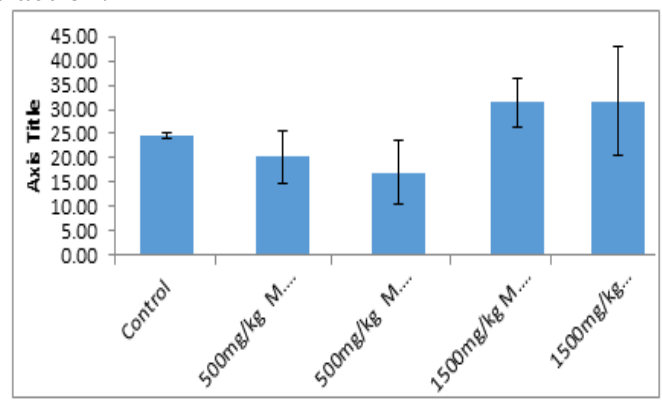

Fig 1: Bar Chart showing change in weight of control rats and rats administered with 500 and $1500 \mathrm{mg} / \mathrm{kg}$ body weight of the extract for 4 and 8 weeks respectively. Values are represented as Mean \pm SEM for each group; $n=5 / g r o u p ; *$ indicates significant difference $(\mathrm{P}<0.05)$ compared with control.

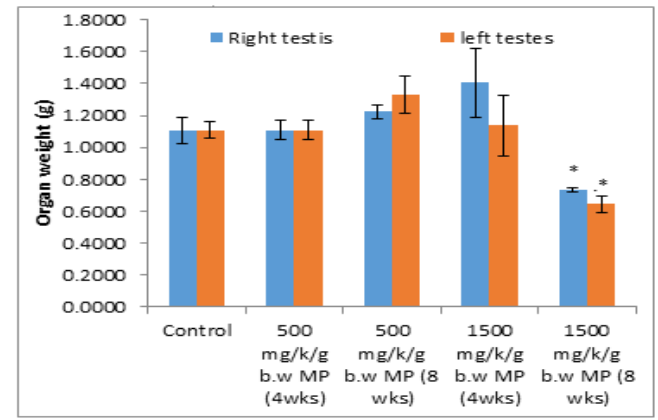

Fig 2: Bar Chart showing testes weight of control rats and rats administered with 500 and $1500 \mathrm{mg} / \mathrm{kg}$ body weight of the extract for 4 and 8 weeks respectively. Values are represented as Mean \pm SEM for each group; $n=5 /$ group; $*$ indicates significant difference $(\mathrm{P}<0.05)$ compared with control.

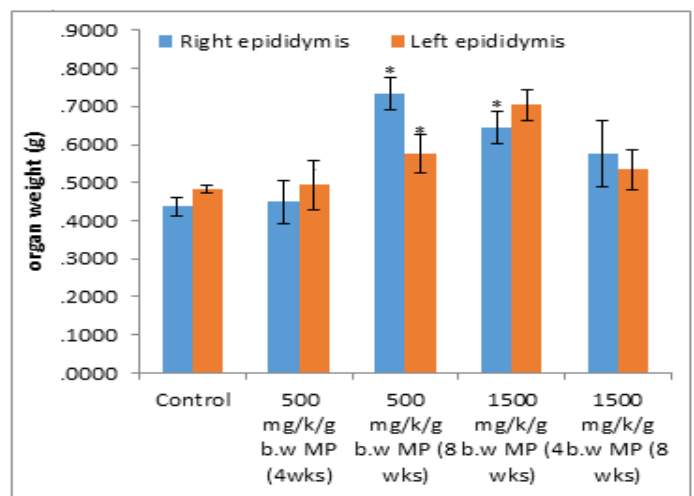

Fig 3: Bar Chart showing epididymal weight of control rats and rats administered with 500 and $1500 \mathrm{mg} / \mathrm{kg}$ body weight of the extract for 4 and 8 weeks respectively. Values are represented as Mean \pm SEM for each group; $n=5 / g r o u p ; *$ indicates significant difference $(\mathrm{P}<0.05)$ compared control. 
There was no significant change in the testicular weight of rats in all treated groups except for group C2 which decreased significantly. However, there was some increase, though not significant in the other groups which therefore can be taken to be consistent with At-Taras et al., 2013 who reported increase in testicular weight, Sertoli cell numbers and total sperm production to be associated with reduced levels of endogenous estrogen.

The observed increase in epididymal weight was general, although this increase was significant in the right epididymis of rats in group B2 and $\mathrm{C} 1$, and left epididymis of rats in group B2. This is in agreement with the report of Daramola et al., 2015 who noted that seed powder of $M$. pruriens caused a significant increase in weight gain, scrotal weight and circumference as well as epididymal and testicular weights. The dearth of research information on the effect of leaf extract of $M$. pruriens on the epididymal weight of adult male Wistar rats makes this consistent report a noteworthy one.

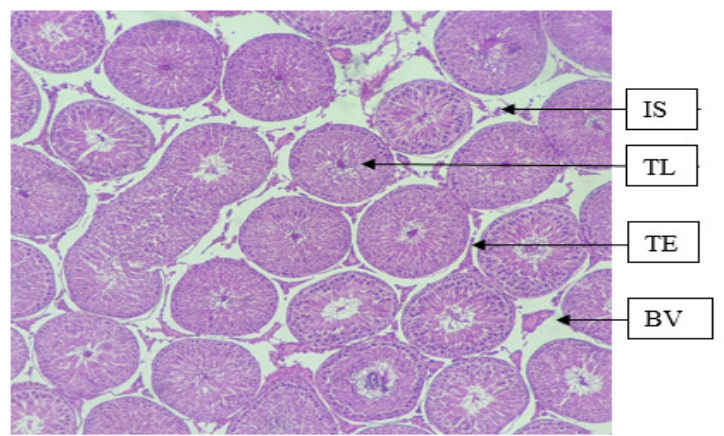

Fig 4: Photomicrograph of the testis of control rats: features shown in micrograph include seminiferous tubule epithelium (TE) seminiferous tubule lumen containing sperm cells (TL); interstitia space (IS) containing Leydig cells (LC); Blood vessel (BV) H\&E x 100 .

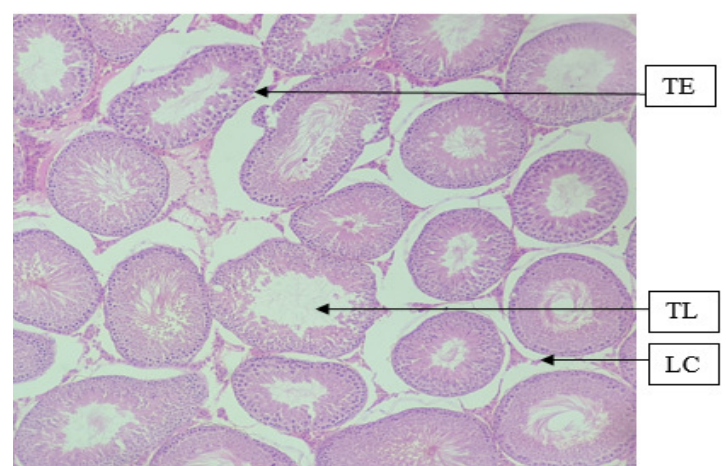

Fig 5: Photomicrograph of the testis of rats treated with $500 \mathrm{mg} / \mathrm{kg}$ body weight of aqueous leaf extract of $M$. pruriens for 4 weeks. Features shown in micrograph include distortion of the serial arrangement of spermatogenic cells in the seminiferous tubule epithelium (TE); absence of tails of spermatozoa in seminiferous tubule lumen (TL); interstitial space (IS) containing interstitial cells of Leydig (LC) appearing normal H\&E x 100.

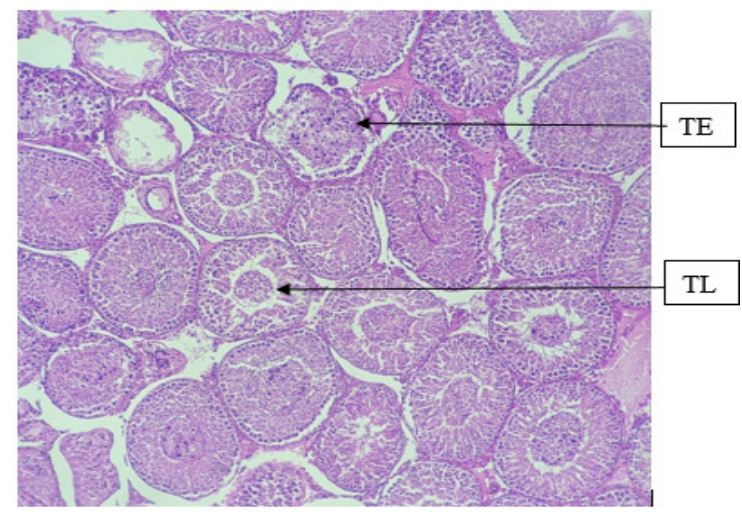

Fig 6: Photomicrograph of the testis of rats treated with $1500 \mathrm{mg} / \mathrm{kg}$ body weight of aqueous leaf extract of $M$. pruriens for 4 weeks. Features shown in micrograph include distortion of the serial arrangement of spermatogenic cells in the seminiferous tubule epithelium (TE); presence of immature cells of the spermatogenic series in seminiferous tubule lumen (TL) H\&E x 100.

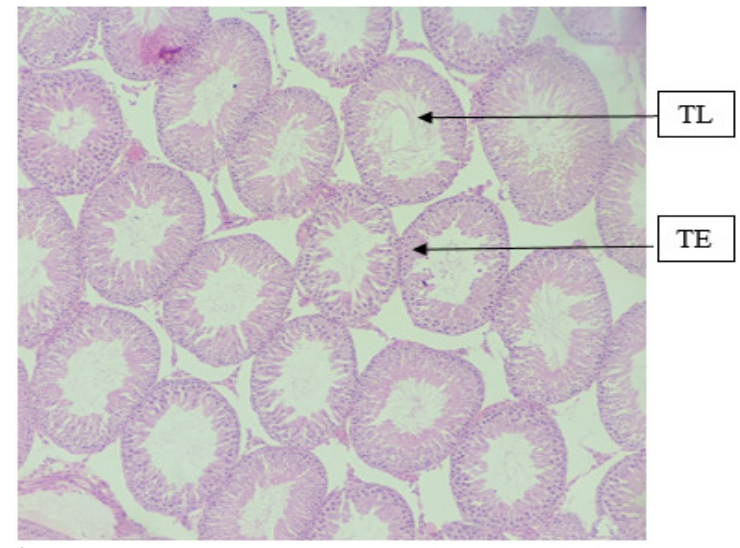

Fig 7: Photomicrograph of the testis of rats treated with $500 \mathrm{mg} / \mathrm{kg}$ body weight of aqueous leaf extract of M. Pruriens for 8 weeks. Features shown in micrograph include distortion of the serial arrangement of spermatogenic cells in the seminiferous tubule epithelium (TE); absence of tails of spermatozoa in seminiferous tubule lumen (TL). H\&E x 100.

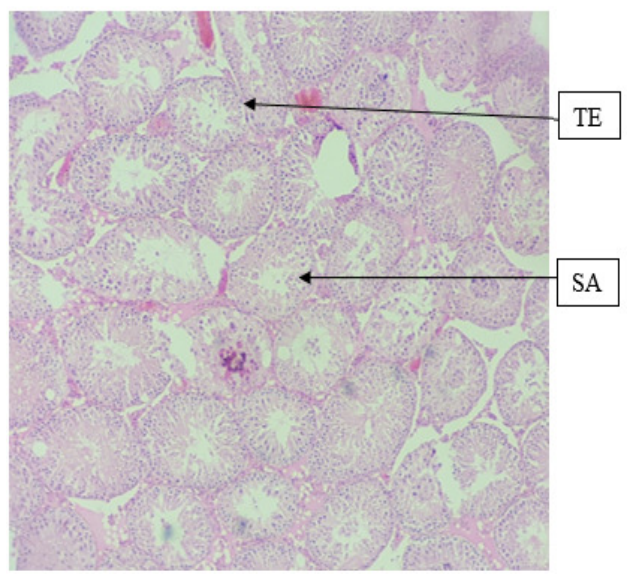

Fig 8: Photomicrograph of the testis of rats treated with $1500 \mathrm{mg} / \mathrm{kg}$ body weight of aqueous leaf extract of M. Pruriens for 8 weeks. Features shown in micrograph include distortion of the serial arrangement of spermatogenic cells in the seminiferous tubule epithelium (TE); spermatogenic arrest (SA) H\&E x 100 


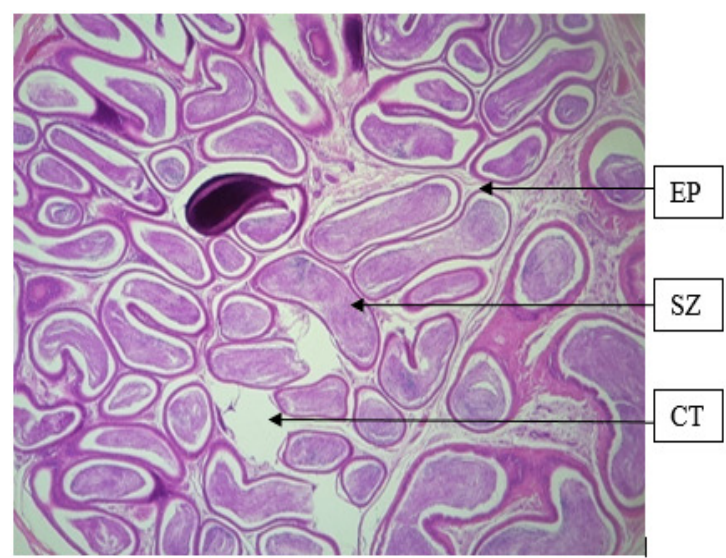

Fig 9: Photomicrograph of the epididymis of control rats: features shown in micrograph include Epithelium (EP), sperm cells in the caudal epididymal lumen (SZ) and connective tissue (CT). H\&E x 100

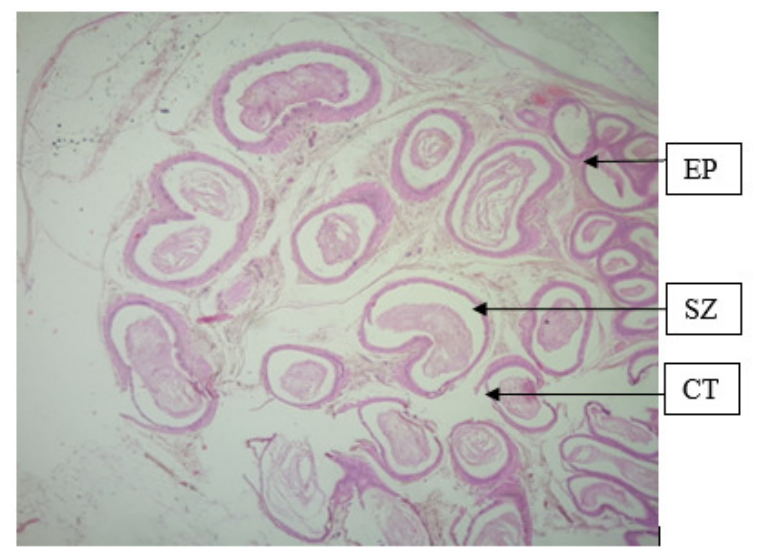

Fig 10: Photomicrograph of the epididymis of rats treated with 500 $\mathrm{mg} / \mathrm{kg}$ body weight of aqueous leaf extract of M. pruriens for 4 weeks. Features shown in micrograph include Epithelium (EP), scanty sperm cells in the caudal epididymal lumen (SZ) and connective tissue (CT). H\&E x 100

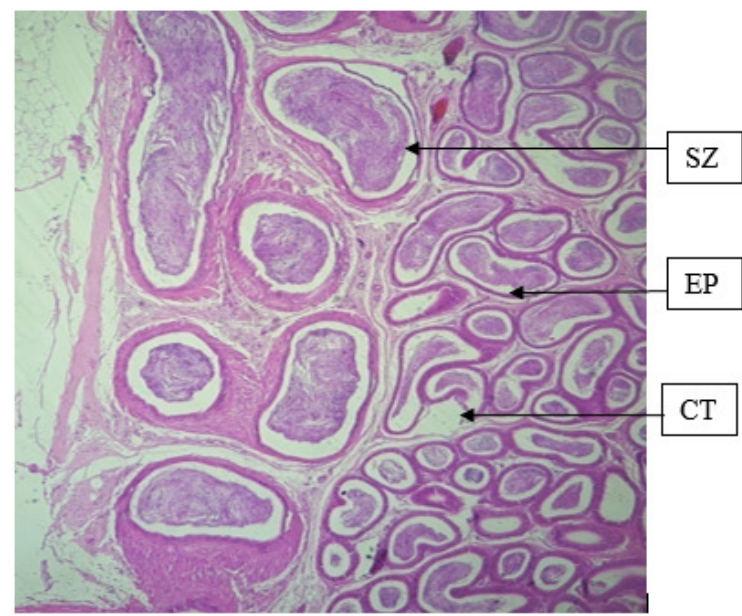

Fig 11: Photomicrograph of the epididymis of rats treated with $1500 \mathrm{mg} / \mathrm{kg}$ body weight of aqueous leaf extract of M. pruriens for 4 weeks. Features shown in micrograph include Epithelium (EP), sperm cells in the caudal epididymal lumen (SZ) and connective tissue (CT). H\&E x 100

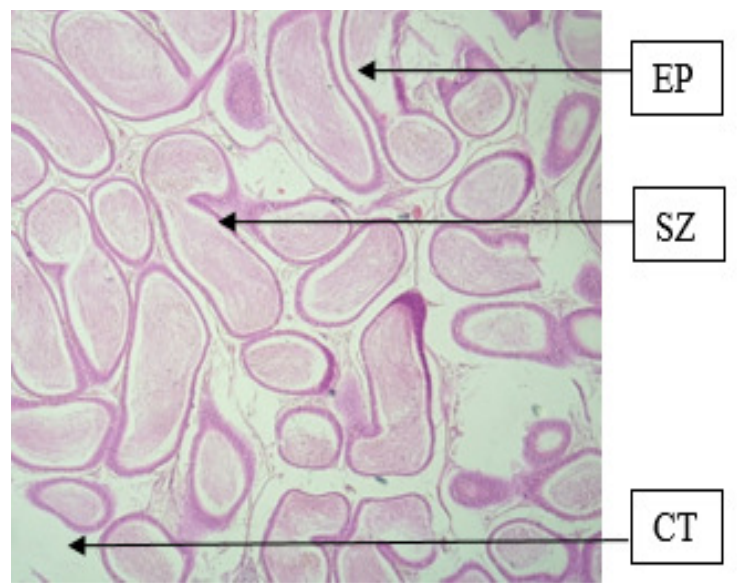

Fig 12: Photomicrograph of the epididymis of rats treated with 500 $\mathrm{mg} / \mathrm{kg}$ body weight of aqueous leaf extract of M. pruriens for 8 weeks. Features shown in micrograph include Epithelium (EP), sperm cells in the caudal epididymal lumen (SZ) and connective tissue (CT). H\&E x 100

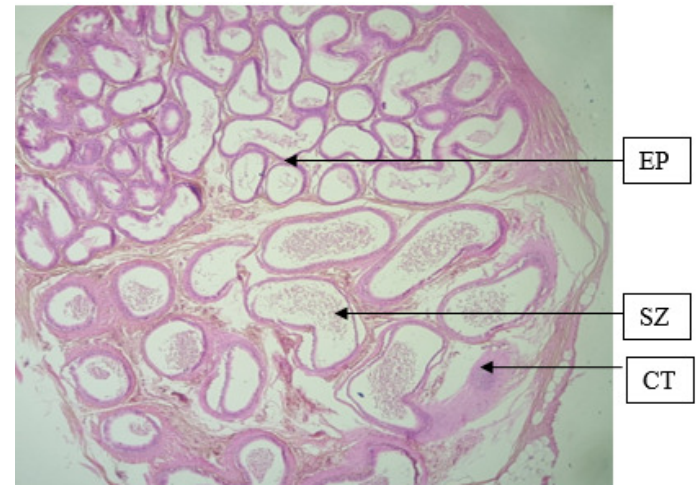

Fig 13: Photomicrograph of the epididymis of rats treated with 1500 $\mathrm{mg} / \mathrm{kg}$ body weight of aqueous leaf extract of M. pruriens for 8 weeks. Features shown in micrograph include Epithelium (EP), scanty sperm cells in the caudal epididymal lumen (SZ) and connective tissue (CT). H\&E x 100

The histological findings in the present study showed distortion in the histomorphology of the testis of rats treated with low and high doses of M. pruriens for both short and long duration. These distortions include alteration of the sequential arrangement of the spermatogenic cells in the epithelium of the seminiferous tubules, presence of immature cells in the lumen of the seminiferous tubules at low dose and spermatogenic arrest at high dose while no distortion was observed in the histomorphology of the caudal epididymis but the caudal epididymal lumen contained fewer spermatozoa in groups B1 and $\mathrm{C} 2$. The histological findings in this study is in agreement with the study conducted by Paul and Joseph (2001), who reported degeneration of sperm cells in the lumen of the seminiferous tubules and epididymis at low dose and complete degeneration of spermatozoa in most lumen of the seminiferous tubules and almost empty epididymal lumen at high dose following 
administration of $M$. pruriens seed powder to male guinea pigs.

Conclusion: This study showed that aqueous leaf extract of Mucuna pruriens distorted the histomorphology of the testis of adult male Wistar rats. As such, males within reproductive age should be cautious in its use.

\section{REFERENCES}

Alo, MN; Okeh, OC; Anyim, C; Orji, JO (2012). The effects of ethanolic extract of Mucuna pruriens leaves on aspartate aminotransferase, alanine aminotransferase and alkaline phosphatase in albino rats. J Nat Prod of Plant Resour. 2(4):465-470

Andersen, HH; Elberling, JP; Arendt-Nielsen, L (2015). "Humam Surrogate models of Histaminergic and non-histaminergic itch".Acta Derm-Venereol. 95:771-7

At-Taras, EE; Beger, T; McCarthy, MJ; Conley, AJ; Nitta-Oda, BJ; Roser, JF (2013). Reducing estrogen synthesis in developing boars increases testis size and total sperm production. $J$ Androl. 27(4):552-9

Dacheux, JL; Castella, S; Gatti, LJ; Dacheux, F (2005). Epididymal cell secretory activities and the role of the proteins in boar sperm epididymis. Theriogenology. 63(2):319-341

Daramola, J; Abiona, JA; Olusyi, S; Olanite, JA; Olaniyi, M; Sowandw, OS; Isaiah, O (2015). Effects of Mucuna pruriens on Sperminograms of West African Bucks. J Trop. and Subtrop. Agrosyst. 18(2):145-150

Evans, WC (2002). Trease and Evans Pharmacology. W.B. Saunders Edinburgh, London

Janardhanan, K; Gurumoorthi, P; Pugalenthi, M (2003).Nutritional potential of 5 accessions of a South Indian tribal pulse. Mucuna pruriens var. utilis.Part 1.The effects of processing methods of LDOPA phytic acid and oligisaccharides. $J$ trop. and subtrop. Agro-ecosyst.1:141-152

Lasserre, A; Barrozo, S; Tezòn, JG; Miranda, PV; Vazquez-Levin, MH (2001). Human epididymal protein and sperm function during fertilization: an update. Biol Res. 34(3-4):165-178

Leavy, M; Trottmann, M; Kölle, S; Liedl, B; Reese, S; Stief, C; Freitag, B; Baugh, J; Spagnoli, G (2017). Effect of elevated $\beta$-estradiol levels on the functional morphology of the testis- New insight. Sci Rep. 7: 39931
Moore, KL; Persaud, TVN (2008). The Urogenital System. In: The Developing Human Clinically Oriented Embryology. Saunders Elsevier

Moore, KL; Dalley, AF; Agur, AM (2010). Abdomen. In: Clinically Oriented Anatomy. Lippincott Williams and Wilkins. Philadeiphia, PA

O'Hara, L; Welsh, M; Saunders, PTK; Smith, LB (2011). Androgens receptors expression in the caput epididymal epithelium is essential for development of the initial segment and epididymal spermatozoa transition. J. Endocrinol. 153(2):718-729

Odebiyi, OO; Sofowora, EA; Powell, J (1999). Phytochemical screening of medicinal plants. J. Int Afr Sym Tradit Pharm Afr med plants. 115:21-22

Paul, U; Joseph, E (2001). Effect of Mucuna pruriens (Horse Eye Bean) on the gonads of male guinea pigs. Phyother Res. 15:99-102

Pugalenthi, M; Vadivel, V; Siddhuraju, P (2005).Alternative food/feed perspectives of an under-utilized legume Mucuna pruriens Utilis-A review.Linn. J Plant Foods Hum Nutr. 60:201-218

Reddy, VB. (2008). "Cowhage-evoked hitch is mediated by a novel cysteine protease: a ligand of proteaseactivated receptors". J. Neurosci. 28(17):4331-4335

Sierens, JE; Sneddon, SF; Collins, F; Millar, MR; Saunders, PT (2005). "Estrogens in Tetis Biology”.Ann. N. Y. Acad. Sci.1061: 65-76

Stojanoski, N (1999). Development of Health Culture in Veles and its region from the past to the end of the $20^{\text {th }}$ Century. Veles: Society of Science and Art. Pp.13-34

Sullivian, R (2004). Male fertility markers, myth or reality. J. Anim Reprod Sci. 82(83):341-347.

Tintinalli, JE; Kelen, GD; Stapczynski, JS (2004). Testes Emergency Medicine: A Comphrensive Study Guide. McGraw-Hill Professional

USDA GRIN Taxonomy (2015). "Mucuna pruriens". Germplasm resources information network. Agricultural research service, United State Department of Agricultural

Vadivel, V; Pugalenthi, M (2010). Studies on the incorporation of velvet beans (Mucuna pruriens Var, Utilis) as an alternative protein source in poultry feed and its effect on growth performance of broiler chickens. Trop Anim Health Prod. 42(7):1367-76 